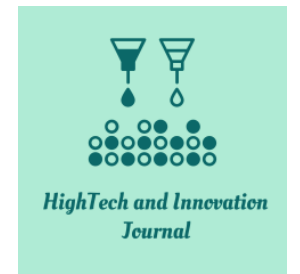

ISSN: 2723-9535

\title{
Analytical Investigation of Higher Education Quality Improvement by Using Six Sigma Approach
}

\author{
Ameen Abdulla M. S. ${ }^{1 *}$, Kavilal E. G. ${ }^{2}$ \\ ${ }^{I}$ Department of Mechanical Engineering, Sree Chitra Thirunal College of Engineering APJ Abdul Kalam Technological University, Kerala, India.
}

Received 23 December 2021; Revised 11 February 2022; Accepted 17 February 2022; Available online 24 February 2022

\begin{abstract}
For over two decades in India, the technical industry's unique selling proposition (USP), with its wide infrastructure of technical institutes, has been capable of supplying best-in-class engineers. But recently, this claim does not hold water. According to the All India Council for Technical Education (AICTE), about 2.6 lakh mechanical engineers graduate every year in India. But the real count of industry ready mechanical engineers is approximately $7 \%$. Hence, there is a need to assess the quality of engineering education in India to reduce the flaws in higher education. The purpose of the paper is to identify the various defects associated with technical education and eliminate those defects using various quality tools. This research is based on the six sigma technique, which is used to assess the quality criteria proposed by the National Board of Accreditation India (NBA). The proposed model is then applied to a typical tier II Indian engineering college located in south India. Six Sigma has two main methodologies: DMAIC and DFSS. The DMAIC (Define, Measure, Analyze, Improve, and Control) methodology is implemented for existing systems, whereas DFSS (Design for Six Sigma) is for assuring quality in new products. In this project, the conclusion is driven by the DMAIC methodology. Various statistical and non-statistical tools are employed in this research. The tools used are CTS-CTQ, SIPOC, Pareto chart, normal process capability analysis, one-way ANOVA, Ishikawa diagram, FMEA, RCBD, and SPC chart. All the statistical processes are done using Minitab analytical software. From the results, it is identified that the factors that have a risk priority number (RPN) greater than 300 need improvement, such as versatility in program curriculum, laboratories and workshops, and credibility among universities. Six Sigma can be achieved by developing proper strategies for mitigating these defects.
\end{abstract}

Keywords: Six Sigma Techniques; Statistical Tools; Non Statistical Tools; Technical Education; Minitab Analytical Software.

\section{Introduction}

We are living in a competitive world which is giving more priority to quality in most aspects. Six Sigma has been effectively implemented in the engineering, retail, and healthcare sectors to reduce defects. Currently, researchers are focusing on implementing six sigma in an unlikely location, i.e., the educational sector. Six Sigma will assist in enhancing the structures that build up the education sector. As parents, faculties, policymakers, and global economic factors begin to place more emphasis on developing quality education, educational establishments will depend even more strongly on the Six Sigma approach to provide the best potential guidance for reducing defects in the educational sector. In the global sense, we can define the term 'Quality' as "Quality is the ability of a product or service to consistently meet or exceed customer expectations". The evolution of Six Sigma comes from inspection. In this Six Sigma project, the customers are industries, society, parents, and institutions [1].

* Corresponding author: ameenabdullams@gmail.com

$>$ This is an open access article under the CC-BY license (https://creativecommons.org/licenses/by/4.0/).

(C) Authors retain all copyrights. 
This project focuses on the implementation of Six Sigma in tier II Indian engineering college to reduce the variations in seven quality criteria (quality criteria proposed by National Board of Accreditation India). The seven criteria is the most critical areas in education such as, vision, Mission, PEO's ,Program curriculum and teaching learning process, course objectives (CO's) and program objectives (PO's), student performance, Faculty information and contribution, facilities and technical support and alumni survey. Six Sigma is employed to reduce the variation and gaining knowledge about education industry. The input of the proposed Six Sigma process is Higher Secondary (HSE) level and lateral entry students and the output of the process will be industry ready mechanical engineers. The main aim of this research is to reduce the variations in the process. Most of the college managements are not bothered about the current industry requirements. In this work, the team identifies most demanded soft skill and hard skill from industries. These requirements are prioritized on the basis of top client requirements to medium client requirements [2-5]. The aim of this research is to make capable a student from HSE level background to industry ready mechanical engineers with the help of six sigma tool. The research aims is achieved by implementing various statistical and non-statistical tools of six sigma. The statistical tools include Pareto Chart, Normal Process capability analysis, Correlation and Regression analysis, One way ANOVA, FMEA, Randomized Complete Block Design (RCBD). The non-statistical tools include CTS-CTQ, SIPOC chart and Ishikawa diagram. Six Sigma has mainly two methodologies DMAIC and DFSS. The DMAIC (Define, Measure, Analyze, Improve and Control) methodology is implementing for existing system whereas DFSS (Design for Six Sigma) is for assuring quality in new products. In this research, the conclusion is driven by statistical approach. This paper is structured as follows, in Define phase the problem identification is highlighted. Data collection-data representation and process capability is analyzed through Measure phase. In Analyze phase the correlation of variables and root cause of the problem is determined, In Improve phase the recommended action is found out, the control phase is used to sustain the changes made in improve phase [6].

\section{Define Phase}

Define is the first phase of a six-sigma project. Here, the problem is defined and the six sigma team is formed. The main aim of the define phase is to clearly define the problem statement through customer analysis. In this defined phase, a professionally qualified team is developed, supported, and dedicated to working on project progress. Customers should be located and identified, high impact assets (CTQs) should be defined, team charters should be developed, and business processes should be mapped. The research team identifies the client requirements, from top level clients to mid-level clients. In this work, the top client is recognized as the Maharatna companies in India, and midlevel companies are referred to as the Miniratna companies in India. Their desired requirements are used as the customer requirements in this research. The problem statement of the project is that: "To reduce the variations of seven criterion data in a typical tier II Indian engineering college and implement a suitable action plan for that." Achieving six sigma is the goal of this research. The timeline for the project is to be set by eight months [7].

The research team includes interested personalities in six sigma. A national agency quotes: "By 2028, mechanical engineers' demand will rise by up to 4\%." After implementing the charter, the next step is to find the voice of the customer (VOC). VOC includes customer expectations, requirements, and opinions. The data from customers is collected through their complaints, field reports, and benchmarking. Customer satisfaction is the primary goal of our project. The term "satisfaction" here means that it is the comparison of expectation to experience. Critical to Satisfaction (CTS) and Critical to Quality (CTQ) are being developed. The CTS-CTQ chart was developed through a brainstorming session. There are seven drivers associated with intermediate to CTS and CTQ. These drivers are further brainstormed into 59 factors [8]. The detailed diagram of CTS-CTQ is given in Figure 1. The goal statement of the research is to achieve six sigma in the mechanical engineering department of a typical tier II Indian engineering college located in south India. For process characteristics and analysis, the team employed the SIPOC chart. This process analysis is used to improve quality delivery and responsiveness. The SIPOC chart is given in Table 1.

\section{Measure Phase}

The measure phase employs more numerical and data analysis than the define phase. This phase involves data collection, data representation, and process capability analysis. The data is collected by face-to-face and online surveys. The 59 factors (CTQ) are classified into four sessions, and the data is processed in accordance with the classification.The various surveys include industry, faculty, student, and alumni surveys. All the surveys are carried out using a 5 point scale. The collected data is represented by using a Pareto chart [9]. The most critical $25 \%$ of defects are taken for analysis in the first phase. The Pareto chart is given in Figure 2. In the Pareto chart, the analysis of 59 factors is listed. The cumulative frequency up to $72 \%$ is taken for deep analysis. Up to $72 \%$, there are 12 factors. The most defective factors involve working in the core field, success rate without backlogs, program curriculum, industry interaction, success rate in a stipulated period of time, new courses introduced, improvement in quality of students admitted, PO's and PSO's, lab, correlation of CO's and PO's, satisfaction in applied level knowledge, and publication of technical magazines. By reducing the variations in these 12 factors, the rate of defects will be reduced by $80 \%$ [10]. Thus, keen observation and deep analysis are required for these 12 factors in the coming phases. After data 
representation and finding the most critical defects, it is necessary to analyse whether the process is capable or not. The process capability analysis is carried out by Minitab analytical software. As a prerequisite for the process capability analysis, the project team goes through the basic concepts in statistics and probability theory. As these two fundamental concepts are necessary to proceed with further six-sigma projects, before going into process capability analysis, the team analyzes whether the process is normal or non-normal. The normality is analyzed through a normal probability plot. Before going into process capability analysis, it is required to calculate the sigma value and mean value. The team analyzes the project on a short-term basis. Thus, a 1.5 sigma shift is accounted for as a compensation factor. If the 1.5 sigma shift is ignored, it will be on a long-term basis. Statistically, six sigma is achieved only on a long-term basis. That is, by ignoring 1.5 sigma, the overall limit will be 4.5 sigma, and the actual value of sigma will be low compared to the short-term basis. The sigma value and mean value are shown in Table 2 .

Table 1. SIPOC chart

\begin{tabular}{|c|c|c|c|c|}
\hline Supplier & Input & Process & Output & Customer \\
\hline \multirow[t]{6}{*}{$\begin{array}{l}\text { - HSE level institution } \\
\text { - Diploma level institution }\end{array}$} & \multirow[t]{6}{*}{$\begin{array}{l}\text { - HSE level students } \\
\text { - Diploma level students }\end{array}$} & $\begin{array}{l}\text { Students were admitted on } \\
\text { the basis of entrance rank }\end{array}$ & \multirow{6}{*}{$\begin{array}{l}\text { HSE/Diploma level } \\
\text { students have been made to } \\
\text { graduate as a world class } \\
\text { mechanical engineers }\end{array}$} & \multirow{6}{*}{$\begin{array}{l}\text { - Industries } \\
\text { - Society } \\
\text { - Institutions } \\
\text { - Parents }\end{array}$} \\
\hline & & & & \\
\hline & & Series of orientation & & \\
\hline & & $\begin{array}{l}4 \text { years of mechanical } \\
\text { engineering education by } \\
\text { achieving } 160 \text { credits }\end{array}$ & & \\
\hline & & Reduce Variation & & \\
\hline & & $\begin{array}{c}\text { Industry Ready Mechanical } \\
\text { Engineers }\end{array}$ & & \\
\hline
\end{tabular}

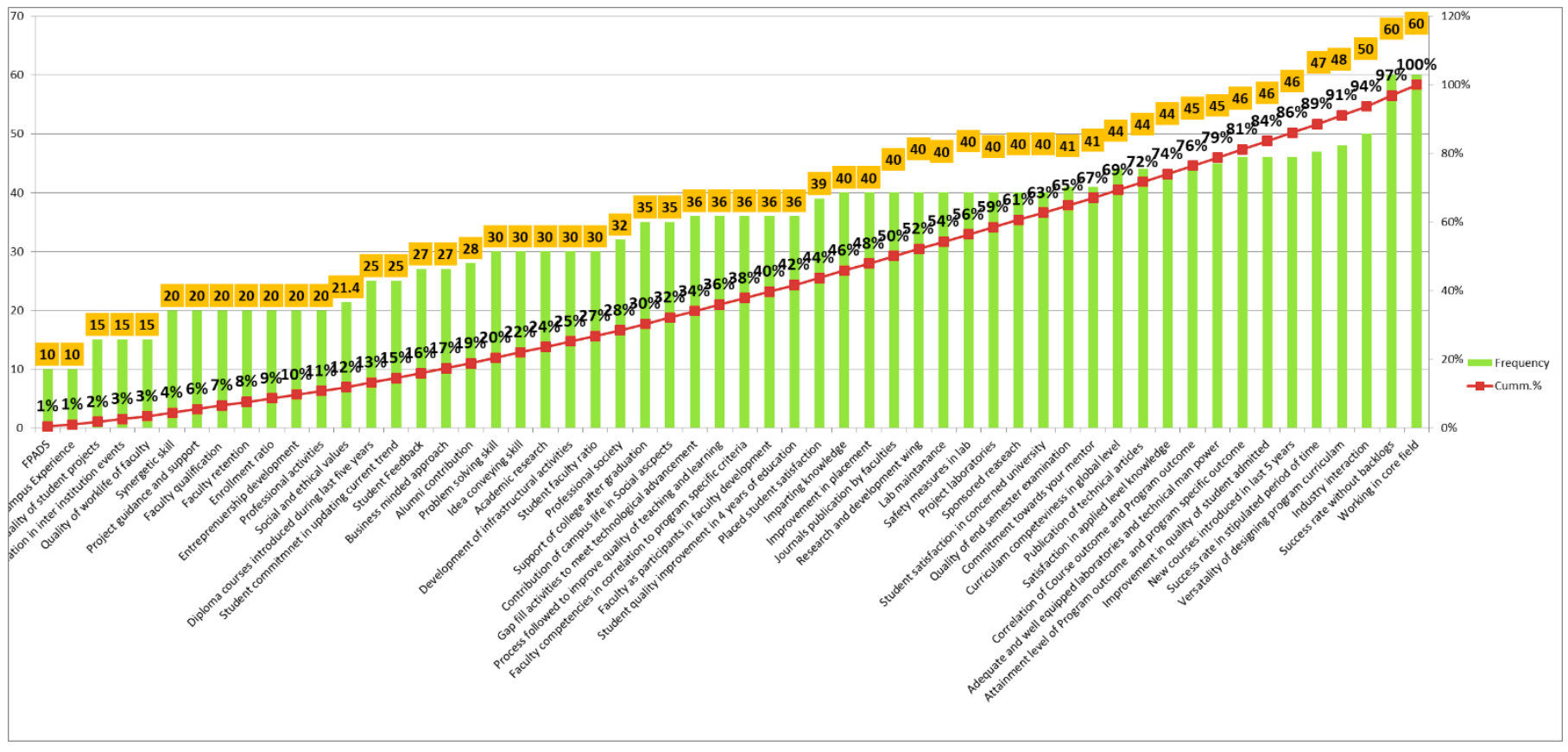

Figure 2. Pareto Chart 


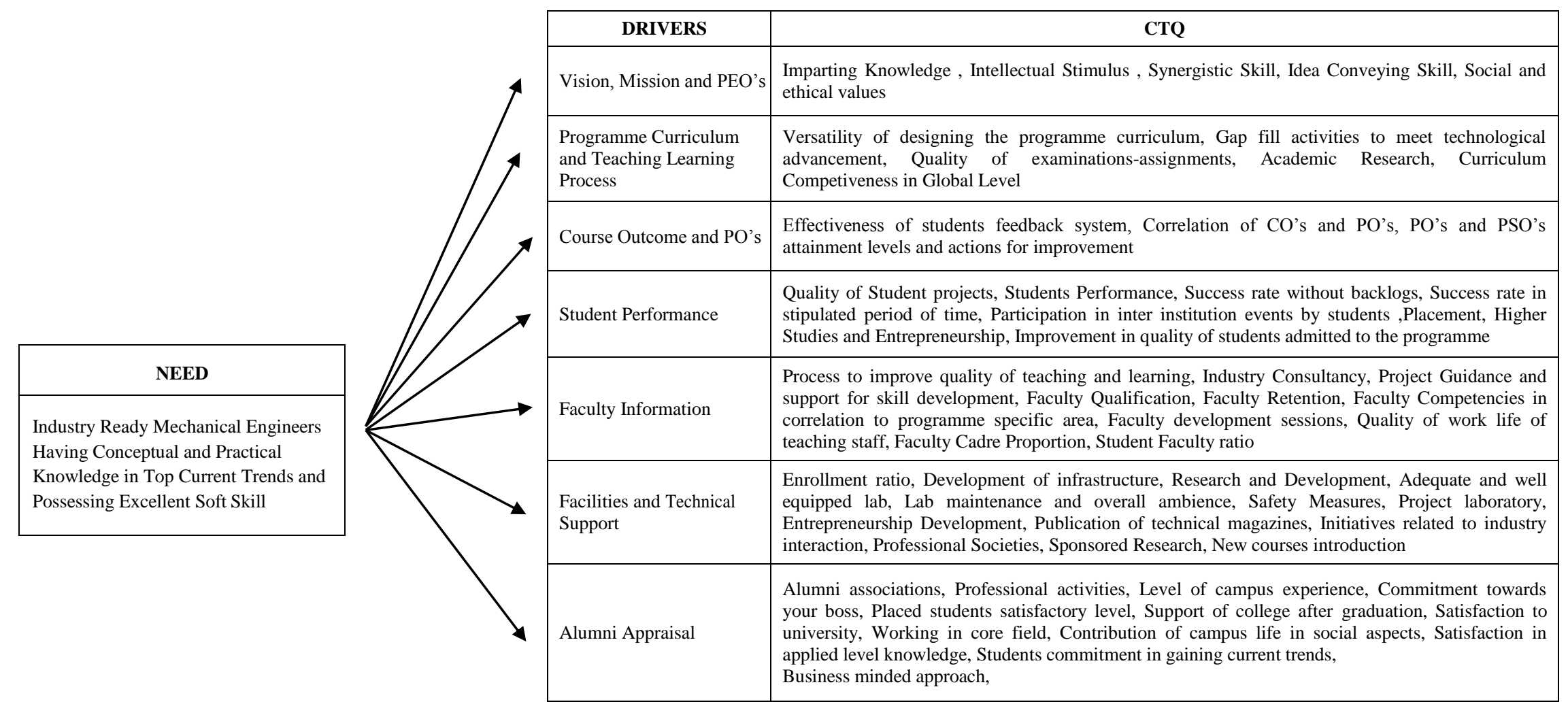

Figure 1. CTS-CTQ 
Table 2. Sigma and Mean value

\begin{tabular}{lcccccc}
\hline \multicolumn{1}{c}{ Criteria } & No. of CTQ & Yield & Defective & DPMO & Standard deviation & Mean value \\
\hline Vision, Mission, PEO's & 5 & 0.716 & 0.284 & 56800 & 3.08 & 71.72 \\
Programme curriculum and teaching & 5 & 0.602 & 0.398 & 79600 & 2.93 & 60.2 \\
learning process & 3 & 0.606 & 0.39 & 130000 & 2.63 & 60.6 \\
CO's and PO's & 10 & 0.65 & 0.34 & 34000 & 3.33 & 65.9 \\
Student Performance & 13 & 0.64 & 0.35 & 26900 & 3.43 & 64 \\
Faculty Information and contribution & 14 & 0.6414 & 0.358 & 25571 & 3.45 & 64.14 \\
Facilities and technical support & 10 & 0.646 & 0.354 & 35400 & 3.33 & 64.6 \\
Alumni Appraisal & & & & & &
\end{tabular}

The overall sigma value for the mechanical department is calculated as 3.16 and mean value as 64.5 . The team uses these values to develop process capability analysis. The process capability analysis is shown in Figure 3.

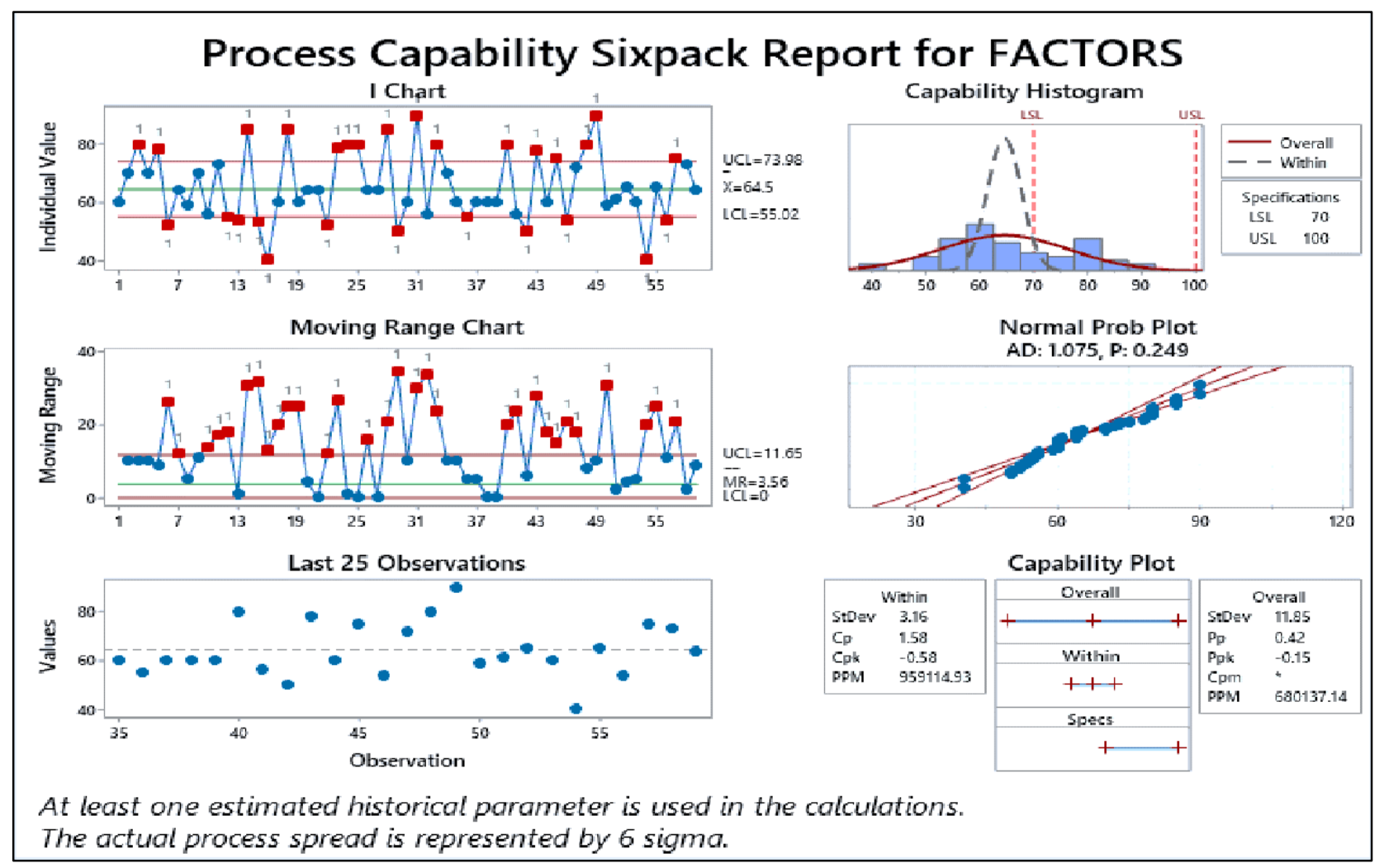

Figure 3. Process capability Sixpack report

From the normal probability plot, it is shown that the data is normally distributed. Hence, the team employs normal process capability analysis. As per the industrial survey, the majority of the mechanical recruiters demanded that their employees needed a minimum of $65 \%$ in all levels of soft skills and hard skills. Therefore, the upper specification limit (USL) is given by 100 and the lower specification limit (LSL) is given by 65. The normal probability distribution curve is outside the specification limit. A small portion of the curve is within the specification limit. So, it is necessary to make the probability curve within the specification limit. Also, the process capability index (Cpk) and the process performance index (Ppk) are less than 1. It implies that the process is not capable of satisfying and meeting the customer requirements (here the customers are mechanical recruiters) [11].

\section{Analyze Phase}

The objective of the analysis phase is to find and validate the root cause of defects and ensure that improvement is focused on causes rather than symptoms. For analysing the root causes of defects, the project team employed hypothesis testing on correlation, regression analysis, and one-way ANOVA. The defects of having a high cumulative frequency from the Pareto chart are selected and, based on that, the above mentioned statistical tool is followed. In hypothesis testing, there are two types of errors: Type I $(\alpha)$ and Type II ( $\beta$ ) errors. In a Type I error, it is mentioned that the process is supposed to be out of statistical control, but in reality, the process is in statistical control. The value of $\alpha=0.05$ and $\beta=0.10$ [12]. Thus the process is keen to focus on to reduce the Type I error $1-\alpha$ is known as the 
confidence level, and 1- $\beta$ is known as the power of the test. For analysing the data, we have to check whether there is a relationship between the CTQ's and Industry Ready Mechanical Engineers (IRME). For that, the team adopts correlation analysis and, based on that, the relationship between CTQ's and IRME is determined. The correlation analysis of each CTQ's and IRME is given in Table 3.

Table 3. Correlation

\begin{tabular}{lc}
\hline \multicolumn{1}{c}{ CTQ } & IRME \\
\hline Vision, Mission and PEO's & 0.799 \\
Student Performance & 0.910 \\
Faculty Information and Contribution & 0.840 \\
Facilities and Technical Support & 0.999 \\
Alumni Appraisal & 0.924 \\
Programme outcome and Course outcome & 0.999 \\
Programme curriculum and teaching learning process & 0.979 \\
\hline
\end{tabular}

From this correlation analysis, we can understand that there is a good relationship between CTQ and IRME. The correlation analysis only gives whether there is a relationship and doesn't give the strength of the relationship. The strength of the relationship is given by the regression analysis. The regression analysis is shown below. The $\mathrm{R}$-square and adjusted R-squared are compared, and it is found that there is a high level of reliability [13]. The regression analysis predicts the value of the dependent variable based on the known value of the independent variable, assuming an average relationship between two or more variables. In this research, the team identified the dependent variable as IRME and the independent variable as 7 criteria. The regression analysis is carried out using Minitab analytical software. The regression equation represents the equation of a straight line, $\mathrm{Yi}=\beta \mathrm{o}+\beta 1 \mathrm{Xi}+\sum \mathrm{i}$. Here, $\beta 1$ represents the slope of the linear regression model. And if the slope is greater, then the autocorrelation between IRME and the criteria will be higher. The team uses regression analysis to determine the intensity of autocorrelation between the dependent variable and the independent variable, which aids the primary session in determining the root causes of the defects [14]. The regression analysis is shown in Table 4.

Table 4. Regression Analysis

\begin{tabular}{|c|c|c|c|c|c|}
\hline \multirow{2}{*}{ Criteria } & \multirow{2}{*}{ Regression equation } & \multicolumn{2}{|c|}{ t- VALUE } & \multicolumn{2}{|c|}{ P- VALUE } \\
\hline & & Constant & Criteria & Constant & Criteria \\
\hline Vision, Mission, PEO’s (VMP) & $\mathrm{IRME}=29.4+0.619 \mathrm{VMP}$ & 1.52 & 2.31 & 0.225 & 0.104 \\
\hline $\begin{array}{l}\text { Programme Curriculum and Teaching Learning } \\
\text { Process (PC\&TLP) }\end{array}$ & $\mathrm{IRME}=-1.27+1.02$ PC\&TLP & -0.31 & 0.776 & 0.776 & 0.001 \\
\hline Programme Outcome and Course Outcome (PO\&CO) & $\mathrm{IRME}=-14.08+0.8090 \mathrm{PO} \& \mathrm{CO}$ & -6.07 & 21.36 & 0.104 & 0.030 \\
\hline Student Performance (SP) & $\mathrm{IRME}=6.8+0.740 \mathrm{SP}$ & 0.52 & 3.81 & 0.638 & 0.032 \\
\hline Faculty Contribution (FC) & $\mathrm{IRME}=12.7+0.7 \mathrm{FC}$ & 0.68 & 2.68 & 0.546 & 0.075 \\
\hline Facilities and Technical Support (F\& TS) & $\mathrm{IRME}=2.23+0.975 \mathrm{~F} \& \mathrm{TS}$ & 1.21 & 34.65 & 0.315 & 0.00 \\
\hline Alumni Appraisal (AA) & $\mathrm{IRME}=10.5+0.753 \mathrm{AA}$ & 0.79 & 4.18 & 0.486 & 0.025 \\
\hline
\end{tabular}

The regression analysis of 7 criteria is shown above. From the regression equation it is found that the programme curriculum and teaching learning process has higher value of $\beta_{0}$ (slope). Thus it have a high autocorrelation with IRME. Thus a keen focus is required in program curriculum as it have a high positive relationship to IRME. PO's and CO's, Facilities and technical support, Student performance are the other criteria which needs to pay greater attention [15].

The analysis of $t$-value is determined on the basis of hypothesis testing.

Here null factor, $\mathrm{HO}$ : No autocorrelation;

\section{H1: Positive autocorrelation.}

Our main focus is to reduce the Type I error as we mentioned above. Thus in the t- test all the 7 criteria have $\mathrm{T}_{\text {stat }}>$ $\mathrm{T}_{\alpha} / 2$ in the two tail test. Thus all the 7 criteria reject $H 0$. Thus it implies that there is a positive autocorrelation exists among criteria and IRME. The P value of all the criteria is less than $\alpha$. That is value of $\alpha=1$. Thus it also implies a strong autocorrelation between the criteria and IRME. To identify the whether the mean is same or not among the factors and client requirements, the team employs one way ANOVA (Analysis of Variance) test. One way ANOVA test is shown in Table 5. 
Table 5. One way ANOVA

\begin{tabular}{|c|c|c|c|c|c|c|}
\hline Method & \multicolumn{6}{|c|}{ ANOVA } \\
\hline Method & Analysi & s of & Varia & ince & & \\
\hline All means are equal & Source & & Adj SS . & Adj MS & Value & -Value \\
\hline Alternative hypothesis Not all means are equal & FACTORS & 17 & 5525 & 325.00 & 3.66 & 0.008 \\
\hline Significance level & Error & 15 & 1332 & 88.83 & & \\
\hline Equal variances were assumed for the analysis. & Total & 32 & 6858 & & & \\
\hline
\end{tabular}

Here, the value of $\mathrm{P}(0.008)$ is less than 0.05 , so the null factor $\mathrm{H} 0$ is rejected and the alternate hypothesis is claimed to be true. That is the mean among the factors, and client requirements are different. For analyzing the relationships between contributing factors, the project team used the Ishikawa diagram. It examines why something happened or might happen by organizing the potential causes into smaller categories [16]. The cause and effect diagram is shown in Figure 4.

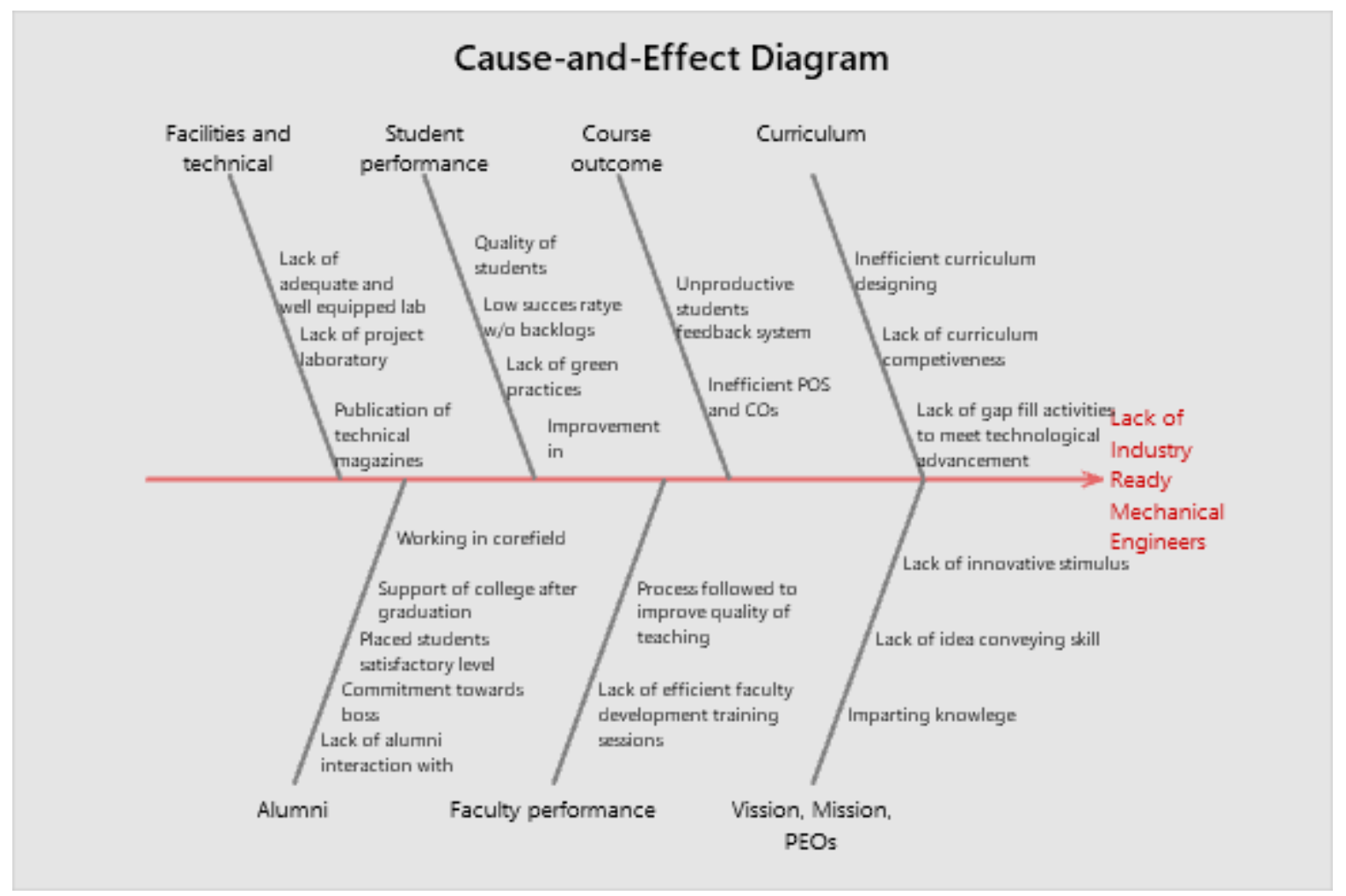

Figure 4. Cause and Effect diagram

The cause and effect diagram is proceeded by using results from Pareto chart, Correlation and regression analysis and ANOVA. The CTQ's having high autocorrelation is depicted in cause and effect diagram.

\section{Improve Phase}

Improve is the fourth phase in the Six Sigma DMAIC cycle. The goal of this stage is to come up with a solution that is based on the problems that were found in the first three phases. The team employs FMEA analysis to determine potential causes, current process control, RPN, recommended action and the concerned section. The detailed FMEA chart is given in Appendix I. The Risk Priority Number (RPN) is a numerical assessment of the risk priority level of a failure mode in an FMEA analysis. It helps the team prioritize risks and make decisions on corrective actions. The value of RPN changes from 1 to 1000 . RPN is calculated as follows: RPN = SEV*OCC*DET. The severity level (SEV) is calculated by potential failure effect, the occurrence level (OCC) is calculated by potential causes, and the DET is calculated by current process control [17-19]. The Randomized Complete Block Design (RCBD) is employed in the research to determine the influence of noise factors affecting students from $1^{\text {st }}$ year to $4^{\text {th }}$ year. The noise factor is divided into 3 categories: noise factor due to students (NF1), noise factor due to college management (NF2), and noise factor due to the environment, university, and government bodies (NF3). The data for RCBD is given in Table 6. 
Table 6. Data for RCBD

\begin{tabular}{cccc}
\hline \multicolumn{3}{c}{ Block V/S Noise Factor } \\
\hline BLOCK & NF1 & NF2 & NF3 \\
\hline 1 & 30 & 50 & 60 \\
2 & 35 & 20 & 62 \\
3 & 55 & 15 & 59 \\
4 & 45 & 10 & 50 \\
\hline
\end{tabular}

From Minitab analytical software, the analysis of variance is obtained. The P-value for the source, block is obtained as 0.77 and the P-value for the noise factor is obtained as 0.039 . The adjusted sum of squares for block and noise factors is 228.3 and 2312.7, respectively. Here, the block represents the students from $1^{\text {st }}$ year to $4^{\text {th }}$ year. The data for RCBD was obtained from a survey conducted at the definition phase [20, 21]. The P-value of the block is $0.770>\alpha(0.05)$. It implies that the null hypothesis is claimed to be true. More or less, all the students are affected by noise factors at the same intensity irrespective of their year. The P-value of the noise factor is $0.039<\alpha$. Thus, the intensity of all the noise factors affecting the students isn't the same. By regression equation, the intensity of NF affecting students is as follows: $\mathrm{NF} 3>\mathrm{NF} 2>\mathrm{NF} 1$.

\section{Control Phase}

The main objective of the control phase is to ensure and maintain the gains obtained from the improvement phase. The team employs a Statistical Process Control (SPC) chart to determine whether the variations in 7 criteria are in statistical process control and it finds that after the recommended actions, the data will fall within specification limits by satisfying the industry requirements [22].

\section{Conclusion}

Quality assurance in mechanical engineering education is an inevitable factor. By conducting various surveys, it has been identified that the demand for mechanical engineers is rising. But the problem is that employers can't find mechanical engineers who are suitable for their industry. The main reason behind it is the outdated curriculum that colleges and universities follow. In addition to a lack of facilities and technical support, faculty development sessions are a major contributor to the shortage of Industry Ready Mechanical Engineers (IRME). In the case of students, they need motivation from faculty, parents, and the good support of alumni. The recommended actions are given by FMEA analysis. The sigma level of the mechanical department of a typical tier II Indian engineering college is 3.16. Six sigma can be achieved in the mechanical engineering department by adopting the DMAIC methodology in a systematic manner. The model of this project can be used in Tier II as well as Tier III engineering colleges. The implication of this project in other institutions can be processed as follows: After defining the voice of the customer and analysing the process capability, the project can be initiated. The root cause of the problem can be determined through correlation and regression analysis. The recommended action can be employed through the FMEA chart, and by using the SPC chart, it can be determined that the altered process is within the control limits.

\section{Declarations}

\subsection{Author Contributions}

Conceptualization, A.A.M.S. and K.E.G.; methodology, A.A.M.S. and K.E.G.; software, A.A.M.S.; formal analysis, A.A.M.S.; data curation, A.A.M.S.; writing - original draft preparation, A.A.M.S.; writing-review and editing, A.A.M.S., and K.E.G.; supervision, K.E.G. All authors have read and agreed to the published version of the manuscript.

\subsection{Data Availability Statement}

The data presented in this study are available in article.

\subsection{Funding}

The authors received no financial support for the research, authorship, and/or publication of this article.

\subsection{Declaration of Competing Interest}

The authors declare that they have no known competing financial interests or personal relationships that could have appeared to influence the work reported in this paper. 


\section{References}

[1] Joseph, M., Yakhou, M., \& Stone, G. (2005). An educational institution's quest for service quality: Customers' perspective. Quality Assurance in Education, 13(1), 66-82. doi:10.1108/09684880510578669.

[2] Shah, N. K., \& Emerick, T. D. (2021). Lean Six Sigma Methodology and the Future of Quality Improvement Education in Anesthesiology. Anesthesia \& Analgesia, 133(3), 811-815. doi:10.1213/ane.0000000000005636.

[3] Davidson, J. M., Price, O. M., \& Pepper, M. (2020). Lean Six Sigma and quality frameworks in higher education - a review of literature. International Journal of Lean Six Sigma, 11(6), 991-1004. doi:10.1108/ijlss-03-2019-0028.

[4] Gupta, S. K., Antony, J., Lacher, F., \& Douglas, J. (2018). Lean Six Sigma for reducing student dropouts in higher education an exploratory study. Total Quality Management \& Business Excellence, 31(1-2), $178-193$. doi:10.1080/14783363.2017.1422710.

[5] Cudney, E. A., \& Furterer, S. L. (2020). Lean Six Sigma in Higher Education: State-of-the-Art Findings and Agenda for Future Research*. Lean Six Sigma in Higher Education, 23-42. doi:10.1108/978-1-78769-929-820201004.

[6] Jenicke, L. O., Kumar, A., \& Holmes, M. C. (2008). A framework for applying six sigma improvement methodology in an academic environment. TQM Journal, 20(5), 453-462. doi:10.1108/17542730810898421.

[7] Helgesen, Ø., \& Nesset, E. (2007). What accounts for students' loyalty? Some field study evidence. International Journal of Educational Management, 21(2), 126-143. doi:10.1108/09513540710729926.

[8] Helgesen, Ø. (2006). Are Loyal Customers Profitable? Customer Satisfaction, Customer (Action) Loyalty and Customer Profitability at the Individual Level. Journal of Marketing Management, 22(3-4), 245-266. doi:10.1362/026725706776861226.

[9] Grosfeld-Nir, A., Ronen, B., \& Kozlovsky, N. (2007). The Pareto managerial principle: When does it apply? International Journal of Production Research, 45(10), 2317-2325. doi:10.1080/00207540600818203.

[10] Harvey, L., \& Barr, P. (2001). Student Feedback a report to the Higher Education Funding Council for England. Centre for Research and Quality, the University of Central England, Birmingham, United Kingdom.

[11] Hörsch, K., \& Rudinger, G. (2009). Der Net Promoter Score an der Universität Bonn In: Rudinger, G., Hörsch, K. \& Krüger, T. (ed.), Forschung und Beratung - DasZentrum für Evaluation und Methoden. Göttingen: Bonn University Press, 75-88, Bonn, North Rhine-Westphalia, Germany.

[12] Gruber, T., Fuß, S., Voss, R., \& Gläser - Zikuda, M. (2010). Examining student satisfaction with higher education services. International Journal of Public Sector Management, 23(2), 105 - 123. doi:10.1108/09513551011022474.

[13] Fredericksen, E., Shea, P., \& Pickett, A. (2000). Factors influencing student and faculty satisfaction in the SUNY learning network. Journal of Asynchronous Learning Networks, 4(2), 245-278.

[14] Hennig-Thurau, T., Langer, M. F., \& Hansen, U. (2001). Modeling and Managing Student Loyalty: An Approach Based on the Concept of Relationship Quality. Journal of Service Research, 3(4), 331-344. doi:10.1177/109467050134006.

[15] Enarsson, L. (1998). Evaluation of suppliers: How to consider the environment. International Journal of Physical Distribution \& Logistics Management, 28(1), 5-17. doi:10.1108/09600039810205935.

[16] Elliott, K. M., \& Healy, M. A. (2001). Key factors influencing student satisfaction related to recruitment and retention. Journal of Marketing for Higher Education, 10(4), 1-11. doi:10.1300/J050v10n04_01.

[17] Deming, W. E. (1993). The new economics for industry. Government, Education, Massachusetts Institute of Technology, Cambridge, MIT press, MA, United States.

[18] Kiang, B. K., Jusoh, M. S., Salleh, S. S. M. M., Ahmad, R., \& Din, M. S. H. (2021). Applying lean six sigma approach: A study in recipe recovery and backup process environment. Proceedings of 8th International Conference on Advanced Materials Engineering \& Technology (ICAMET 2020). doi:10.1063/5.0055628.

[19] Cudney, E. A., Venuthurumilli, S. S. J., Materla, T., \& Antony, J. (2020). Systematic review of Lean and Six Sigma approaches in higher education. Total Quality Management \& Business Excellence, 31(3-4), 231-244. doi:10.1080/14783363.2017.1422977.

[20] Douglas, J., \& Douglas, A. (2006). Evaluating Teaching Quality. Quality in Higher Education, 12(1), 3-13. doi:10.1080/13538320600685024.

[21] Donaldson, B., \& Runciman, F. (1995). Service quality in further education: An insight into management perceptions of service quality and those of the actual service provider. Journal of Marketing Management, 11(1-3), $243-256$. doi:10.1080/0267257X.1995.9964340.

[22] DeBourgh, G. A. (2003). Predictors of student satisfaction in distance-delivered graduate nursing courses: What matters most? Journal of Professional Nursing, 19(3), 149-163. doi:10.1016/S8755-7223(03)00072-3. 


\section{Appendix I: FMEA Chart}

\begin{tabular}{|c|c|c|c|c|c|c|c|c|c|c|}
\hline Process Step & Potential Failure Mode & Potential Failure Effect & SEV & Potential Causes & OCC & Current Process Control & DET & RPN & Action Recommended & $\begin{array}{c}\text { Concerned } \\
\text { Department }\end{array}$ \\
\hline \multirow{3}{*}{$\begin{array}{l}\text { Facilities and } \\
\text { Technical Support }\end{array}$} & $\begin{array}{l}\text { Adequate and well } \\
\text { equipped laboratories }\end{array}$ & $\begin{array}{l}\text { Lack skills in practical } \\
\text { knowledge }\end{array}$ & 6 & $\begin{array}{l}\text { Lack of funding } \\
\text { Lack of awareness in } \\
\text { practical session }\end{array}$ & 7 & $\begin{array}{l}\text { Some conv M/C like Lathe, Shaper } \\
\text { are installed }\end{array}$ & 8 & 336 & $\begin{array}{l}\text { Conventional machines should be } \\
\text { replaced by CNC Lab, Automation lab, } \\
\text { D/S research lab, Fire project lab, } \\
\text { Industrial engineering lab Thermo fluid } \\
\text { and energy systems lab }\end{array}$ & $\begin{array}{l}\text { College mgmt. } \\
\text { Govt. }\end{array}$ \\
\hline & Project laboratories & $\begin{array}{l}\text { Not enthused to use lab } \\
\text { for their project }\end{array}$ & 6 & $\begin{array}{l}\text { Funding } \\
\text { Lack of awareness }\end{array}$ & 6 & $\begin{array}{l}\text { In some colleges one or two labs are } \\
\text { assigned as project laboratories }\end{array}$ & 6 & 216 & $\begin{array}{l}\text { Funding should implemented, PL should } \\
\text { include all major sessions including } \\
\text { manuf., \& automobile }\end{array}$ & $\begin{array}{l}\text { Gov. College } \\
\text { mgmt. }\end{array}$ \\
\hline & $\begin{array}{l}\text { Publication of tech } \\
\text { articles }\end{array}$ & $\begin{array}{l}\text { Students aren't awarded } \\
\text { current industry trends }\end{array}$ & 5 & Lack of awareness & 6 & $\begin{array}{l}\text { Some technical article is quoted in } \\
\text { college and university magazine }\end{array}$ & 4 & 120 & $\begin{array}{l}\text { Students and faculties research articles } \\
\text { should publish in the label of college }\end{array}$ & $\begin{array}{l}\text { University } \\
\text { College mgmt. }\end{array}$ \\
\hline \multirow{6}{*}{ Alumni appraisal } & $\begin{array}{l}\text { Lack of alumni } \\
\text { interaction with students }\end{array}$ & Students aren't motivated & 4 & $\begin{array}{l}\text { There is no Alumni meet with } \\
\text { the students }\end{array}$ & 5 & No such initiative is present & 6 & 120 & $\begin{array}{l}\text { Student should interact in alumni } \\
\text {.Maintain good relationships with seniors }\end{array}$ & $\begin{array}{l}\text { College } \\
\text { University }\end{array}$ \\
\hline & $\begin{array}{l}\text { Commitment towards } \\
\text { Boss }\end{array}$ & $\begin{array}{l}\text { Affect the relation } \\
\text { between employer and } \\
\text { employee }\end{array}$ & 5 & $\begin{array}{l}\text { Not willing to share their } \\
\text { project discussion with } \\
\text { mentor }\end{array}$ & 4 & $\begin{array}{l}\text { An hour is implemented in the first } \\
\text { and second year for soft skill }\end{array}$ & 5 & 100 & $\begin{array}{l}\text { Share your project progress with mentor. } \\
\text { A good relationship with faculties will } \\
\text { help to maintain a good relationship with } \\
\text { their Boss }\end{array}$ & $\begin{array}{l}\text { Students } \\
\text { Faculties }\end{array}$ \\
\hline & $\begin{array}{l}\text { Placed student } \\
\text { satisfactory level }\end{array}$ & $\begin{array}{l}\text { It might affect their } \\
\text { career growth }\end{array}$ & 6 & $\begin{array}{l}\text { Some students have mind to } \\
\text { work in the core field }\end{array}$ & 6 & $\begin{array}{l}\text { No such motivation is shared to } \\
\text { students }\end{array}$ & 6 & 216 & $\begin{array}{l}\text { Grow a mindset to work in any field } \\
\text { \&flourish in their field }\end{array}$ & $\begin{array}{l}\text { Faculty } \\
\text { Parents }\end{array}$ \\
\hline & $\begin{array}{l}\text { Support of college after } \\
\text { graduation }\end{array}$ & $\begin{array}{l}\text { Fresh Eng. graduates they } \\
\text { are facing a new world }\end{array}$ & 7 & $\begin{array}{l}\text { Faculties and colleges are not } \\
\text { awarded about these issue }\end{array}$ & 6 & $\begin{array}{l}\text { A relationship with faculties is to be } \\
\text { maintained }\end{array}$ & 5 & 210 & $\begin{array}{l}\text { Maintain a good relationship with } \\
\text { faculties Students by placement unit in } \\
\text { college }\end{array}$ & $\begin{array}{l}\text { College } \\
\text { Faculty }\end{array}$ \\
\hline & Satisfaction to university & $\begin{array}{l}\text { It might affect the } \\
\text { credibility among Univ. }\end{array}$ & 8 & $\begin{array}{l}\text { Result timing, feedback, } \\
\text { Inadequate staff }\end{array}$ & 8 & $\begin{array}{l}\text { Some initiative taken to improve the } \\
\text { scheduled session }\end{array}$ & 7 & 448 & $\begin{array}{l}\text { Publish result in scheduled time } \\
\text { Respond to student feedback }\end{array}$ & University \\
\hline & Working in core field & $\begin{array}{l}\text { Students aren't placed in } \\
\text { core field }\end{array}$ & 9 & $\begin{array}{l}\text { Inadequacy in applied level } \\
\text { knowledge }\end{array}$ & 8 & $\begin{array}{l}\text { Some-IT co. preferring for mechanical } \\
\text { engineering for their } \mathrm{R} \& \mathrm{D} \text { division }\end{array}$ & 6 & 432 & $\begin{array}{l}\text { Student should cope up with applied } \\
\text { level knowledge. CGPU cell have to } \\
\text { invite product based company into } \\
\text { campus regardless of their size }\end{array}$ & $\begin{array}{l}\text { CGPU } \\
\text { Faculties }\end{array}$ \\
\hline $\begin{array}{l}\text { Vision, Mission, } \\
\text { PEO }\end{array}$ & $\begin{array}{l}\text { Lack of innovative } \\
\text { stimulus }\end{array}$ & $\begin{array}{l}\text { May affect their future } \\
\text { projects }\end{array}$ & 4 & $\begin{array}{l}\text { There is no innovative } \\
\text { laboratories innovative } \\
\text { practices }\end{array}$ & 4 & $\begin{array}{l}\text { Some student events are conducted bit } \\
\text { is mainly focused in automobile. }\end{array}$ & 6 & 120 & $\begin{array}{l}\text { Innovation laboratories is to be } \\
\text { implemented } \\
\text { Innovation practices should introduce as } \\
\text { a core course in academic regulation }\end{array}$ & $\begin{array}{l}\text { University } \\
\text { Students }\end{array}$ \\
\hline
\end{tabular}




\begin{tabular}{|c|c|c|c|c|c|c|c|c|c|c|}
\hline \multirow{2}{*}{$\begin{array}{l}\text { Program and } \\
\text { course outcomes }\end{array}$} & $\begin{array}{l}\text { Effectiveness of } \\
\text { students' feedback } \\
\text { system. }\end{array}$ & $\begin{array}{l}\text { Students losing } \\
\text { credibility in feedback } \\
\text { system }\end{array}$ & 4 & $\begin{array}{l}\text { No assigned/ staff/ motivator } \\
\text { to meet students' feedback }\end{array}$ & 7 & $\begin{array}{l}\text { A feedback system box is installed in } \\
\text { campus. }\end{array}$ & 4 & 112 & Appoint a counselor /motivator & $\begin{array}{l}\text { Faculties in } \\
\text { concerned field. } \\
\text { College } \\
\text { management }\end{array}$ \\
\hline & $\begin{array}{l}\text { Effectiveness of PO'S \& } \\
\text { CO'S }\end{array}$ & $\begin{array}{l}\text { Might affect the most } \\
\text { demanded soft skill and } \\
\text { hard skill. }\end{array}$ & 5 & $\begin{array}{l}\text { Unawared about current } \\
\text { industry trends }\end{array}$ & 5 & Updating curriculum periodically & 5 & 125 & $\begin{array}{l}\text { The stated PO's will have a good } \\
\text { correlation to courses taught }\end{array}$ & $\begin{array}{l}\text { Faculties, } \\
\text { university / } \\
\text { college } \\
\text { management }\end{array}$ \\
\hline $\begin{array}{l}\text { Program } \\
\text { curriculum and } \\
\text { teaching learning } \\
\text { process }\end{array}$ & $\begin{array}{l}\text { Lack of versatility in } \\
\text { designing program } \\
\text { curriculum }\end{array}$ & $\begin{array}{l}\text { The gap will exist } \\
\text { among industry trend } \\
\text { and student knowledge }\end{array}$ & 8 & $\begin{array}{l}\text { Curriculum designing } \\
\text { committee is not aware about } \\
\text { current trends. } \\
\text { The designing team is not } \\
\text { bothered about students' } \\
\text { future }\end{array}$ & 8 & $\begin{array}{l}\text { In the name of curriculum revising, } \\
\text { some core concepts in mechanical } \\
\text { engineering is removed instead of } \\
\text { curriculum enrichment. }\end{array}$ & 9 & 512 & $\begin{array}{l}\text { Add the subjects in curriculum - } \\
\text { Python with machine learning, } \\
\text { HVAC with practical sessions, } \\
\text { Enrich product development, } \\
\text { Reduce the conv. topics in IC Eng. } \\
\text { Conv. manuf. and add the core } \\
\text { concepts in electric \& hybrid } \\
\text { vehicles \& non-conv m/c process, } \\
\text { Add a } 50 \text { hr. session in various } \\
\text { maintenance dept. and include } 20 \\
\text { hr. session in practical diagnostic } \\
\text { skill session, Add a } 54 \text { hour } \\
\text { session regarding Eng. energy }\end{array}$ & $\begin{array}{l}\text { University or } \\
\text { college } \\
\text { management. } \\
\text { Introduce MOOC } \\
\text { chapters }\end{array}$ \\
\hline \multirow{5}{*}{$\begin{array}{l}\text { Student } \\
\text { Performance }\end{array}$} & $\begin{array}{l}\text { Quality of student } \\
\text { admitted to programme }\end{array}$ & $\begin{array}{l}\text { *There occurs a gap btw } \\
\text { advanced and slow } \\
\text { learner }\end{array}$ & 6 & $\begin{array}{l}\text { Students are directly entering } \\
\text { in Eng. course }\end{array}$ & 6 & $\begin{array}{l}\text { A low duration orientation class is } \\
\text { provided }\end{array}$ & 7 & 252 & $\begin{array}{l}\text { *slow learners and students done } \\
\text { their schooling in regional language } \\
\text { *bridge course should introduce }\end{array}$ & $\begin{array}{l}\text { College, } \\
\text { faculty }\end{array}$ \\
\hline & $\begin{array}{l}\text { *Low success rate w/o } \\
\text { backlogs }\end{array}$ & $\begin{array}{l}\text { Can't appear in all } \\
\text { interview }\end{array}$ & 6 & $\begin{array}{l}\text { Lack of learning source, } \\
\text { Negligence attitude towards } \\
\text { board exam }\end{array}$ & 4 & PTA meeting arranged & 5 & 120 & $\begin{array}{l}\text { A Scale of } 0-10 \text { relative to peers } \\
\text { in the class. Marks } 50 \% \text { below } \\
\text { attend special class }\end{array}$ & Faculty \\
\hline & Lack of green practices & $\begin{array}{l}\text { It might affect the ethical } \\
\text { values of students }\end{array}$ & 3 & No such awareness is present & 4 & Stoppage of straw is implemented & 3 & 36 & $\begin{array}{l}\text { Public transportation, paperless } \\
\text { office, plastic free campus, install } \\
\text { renewable energy sources }\end{array}$ & $\begin{array}{l}\text { Student Faculty } \\
\text { mgmt. }\end{array}$ \\
\hline & $\begin{array}{l}\text { Quality of sem. internal } \\
\text { assignment questions }\end{array}$ & $\begin{array}{l}\text { Not cope up with } \\
\text { competitive } \\
\text { environment }\end{array}$ & 5 & $\begin{array}{l}\text { If the questions re set in } \\
\text { competitive basis, slow } \\
\text { learner cant adapt the system }\end{array}$ & 6 & $\begin{array}{l}\text { University model question is } \\
\text { implemented }\end{array}$ & 5 & 150 & $\begin{array}{l}\text { Include questions with conceptual } \\
\text { knowledge }\end{array}$ & $\begin{array}{l}\text { Faculty } \\
\text { University } \\
\text { mgmt. }\end{array}$ \\
\hline & $\begin{array}{l}\text { Improvement in } \\
\text { entrepreneurship } \\
\text { development }\end{array}$ & $\begin{array}{l}\text { A bulliness minded } \\
\text { approach can't be } \\
\text { implemented in students }\end{array}$ & 5 & $\begin{array}{l}\text { Students are having a } \\
\text { mindset to settle down in } \\
\text { low risky areas }\end{array}$ & 5 & An EDC is present in the campus & 3 & 75 & $\begin{array}{l}\text { Provide the students with } \\
\text { awareness, camp, motivation, } \\
\text { provide adequate fund for that }\end{array}$ & Gov. Mgmt. \\
\hline
\end{tabular}

